\title{
Sensitivity loss by Corynespora cassiicola, isolated from soybean, to the fungicide carbendazim
}

\author{
Aveline Avozani ${ }^{1}$, Erlei Melo Reis ${ }^{2}$ and Rosane Baldiga Tonin ${ }^{1}$
}

${ }^{1}$ Faculdade de Agronomia e Medicina Veterinária, Universidade de Passo Fundo. ${ }^{2} \mathrm{OR}$ - Melhoramento de sementes Ltda, Passo Fundo, RS Autor para correspondência: Aveline Avozani (avelinebio3@yahoo.com.br)

Data de chegada: 25/11/2013. Aceito para publicação em: 16/06/2014.

$10.1590 / 0100-5405 / 1928$

\section{ABSTRACT}

Avozani, A.; Reis, E. M; Tonin, R. B. Sensitivity loss by Corynespora cassiicola, isolated from soybean, to the fungicide carbendazim. Summa Phytopathologica, v.40, n.2, p.273-276, 2014.

Soybean target leaf spot, caused by the fungus Corynespora cassiicola, is controlled especially by leaf application of fungicides. In the last seasons, in the central-west region of Brazil, the disease chemical control efficiency has been low. This led to the hypothesis that the control failure could be due to the reduction or loss of the fungus sensitivity to fungicides. To clarify this fact, in vitro experiments were conducted to determine mycelial sensitivity of five $C$. cassiicola isolates to fungicides. Mycelial growth was assessed based on the growth of the mycelium on the culture medium, in Petri dishes. The medium potato-dextrose-agar was supplemented with the concentrations $0 ; 0.01 ; 0.1 ; 1 ; 10 ; 20$ and $40 \mathrm{mg} / \mathrm{L}$ of the active ingredients carbendazim, cyproconazole, epoxiconazole, flutriafol and tebuconazole.
The experiment was conducted and repeated twice in a controlled environment, temperature of $25 \pm 2^{\circ} \mathrm{C}$ and photoperiod of 12 hours. Data on the percentage of mycelial inhibition were subjected to logarithmic regression analysis and the concentration that inhibits $50 \%$ of the mycelial growth $\left(\mathrm{IC}_{50}\right)$ was calculated. Loss of sensitivity to carbendazim was observed for three fungal isolates, $\mathrm{IC}_{50}>40 \mathrm{mg} / \mathrm{L}$. Considering all five isolates, the $\mathrm{IC}_{50}$ for tebuconazole ranged from 1.89 to $2.80 \mathrm{mg} / \mathrm{L}$, for epoxiconazol from 2.25 to 2.91 , for cyproconazole from 9.21 to $20.32 \mathrm{mg} / \mathrm{L}$, and for flutriafol from 0.77 to $2.18 \mathrm{mg} / \mathrm{L}$. In the absence of information on the reference $\mathrm{IC}_{50}$ determined for wild isolates, the lowest values generated in our study can be used as standard to monitor the fungus sensitivity.

Additional keywords: Chemical control, Glycine max, target leaf spot, fungicide resistance.

\section{RESUMO}

Avozani, A.; Reis, E. M; Tonin, R. B. Perda da sensibilidade de Corynespora cassiicola, isolado de soja, ao fungicida carbendazim. Summa Phytopathologica, v.40, n.2, p.273-276, 2014.

A mancha alvo da soja, causada pelo fungo Corynespora cassiicola, é controlada principalmente pela aplicação foliar de fungicidas. Nas últimas safras, na região Centro-Oeste, verificou-se a baixa eficiência do controle químico da doença. Levantou-se a hipótese de que a falha de controle poderia ser atribuída à redução ou perda da sensibilidade do fungo aos fungicidas. Para esclarecer o fato, experimentos foram realizados para determinar a sensibilidade miceliana, in vitro, de cinco isolados de C. cassiicola a fungicidas. $\mathrm{O}$ crescimento miceliano foi avaliado pelo crescimento do micélio no meio de cultura, em placas de petri. O meio de batata-sacarose-ágar foi suplementado com concentrações de $0 ; 0,01$; 0,$1 ; 1 ; 10 ; 20$ e $40 \mathrm{mg} / \mathrm{L}$ dos ingredientes ativos carbendazim, ciproconazol, epoxiconazol, flutriafol e tebuconazol. O experimento foi conduzido e repetido por duas vezes em ambiente controlado, temperatura de $25 \pm 2^{\circ} \mathrm{C}$ e fotoperíodo de 12 horas, com quatro repetições. Os dados da porcentagem de inibição miceliana foram submetidos à análise de regressão logarítmica e calculada a concentração que inibe $50 \%$ do crescimento miceliano $\left(\mathrm{CI}_{50}\right)$. A perda da sensibilidade ao carbendazim foi constatada para três isolados do fungo com $\mathrm{CI}_{50}>40 \mathrm{mg} / \mathrm{L}$. Para os cinco isolados, a $\mathrm{CI}_{50}$ para tebuconazol variou de 1,89 a 2,80 mg/L, para epoxiconazol de 2,25 a 2,91, para o ciproconazol de 9,21 a $20,32 \mathrm{mg} / \mathrm{L}$ e para o flutriafol de 0,77 a $2,18 \mathrm{mg} / \mathrm{L}$. Na falta de informação da $\mathrm{CI}_{50}$ de referência determinada para isolados selvagens, os valores mais baixos gerados nesse trabalho podem ser utilizados como padrão para o monitoramento da sensibilidade do fungo.

Palavras-chave adicionais: Controle químico, Glycine max, mancha alvo, resistência a fungicidas.

Soybean [Glycine max (L.) Merr.] crop area in Brazil, in the 2012/13 growing season, reached 27 million hectares (4). Most of the crop is grown under monoculture and no-till, which favors the occurrence and the severity of a large number of diseases.

The fungus Corynespora cassiicola (Berk. \& Curtis) Wei (1950) causes target spot on soybean leaves and attacks more than 280 plant species in over 70 countries (nt.ars-grin.gov/fungaldatabases/index. (fm,).

Considering soybean crop, target leaf spot (TLS) has been a concern for Brazilian producers and researchers due to its increasing occurrence, severity and great damage when not properly controlled (9). Its increased occurrence and severity in Brazil could be related to prolonged use of monoculture, no-till, use of susceptible cultivars and changes in weather patterns such as frequent rainfall during the vegetative growth stages.

There are few fungicide options for TLS control. The most used MBC (methyl benzimidazole carbamate) fungicide is carbendazim, which is efficient to control TLS in large areas receiving many sprayings 
per season. For cultivars susceptible to TLS, however, control has become less efficient (9).

In the central-west region of Brazil, farmers have questioned the efficiency of TLS chemical control. Even after multiple fungicide applications, control has not been satisfactory. Carbendazim has been broadly used at sub-doses, mixed with herbicides, insecticides, and ready-mixes of DMI and QoI fungicides, without any spraying rule for soybean fields. Every time the crop is sprayed, carbendazim is added as a tank mixture, but this is not technically supported.

Reduction/loss of the fungus sensitivity to fungicides is the result of a fundamental property of living organisms, their ability to adapt to different environmental conditions (7). Fungal strains can reduce or lose their sensitivity to fungicides due to the pathogen genetic variability. The constant use of chemical compounds acting on specific sites makes a directional selection pressure on the fungus to adapt to the new condition by partially or completely losing the sensitivity to fungicides (7).

We hypothesized that the control failure faced by farmers may be due to the threat of carbendazim fungicide to the fungus.

The aims of our study were: (i) to determine the in vitro mycelial sensitivity of $C$. cassiicola soybean isolates to some commonly used fungicides, and (ii) to determine their inhibitory concentration $\left(\mathrm{IC}_{50}\right)$.

Sensitivity to fungicides was evaluated based on the mycelial growth of fungi on the solid culture medium potato-dextrose-agar [39 $\mathrm{g} / \mathrm{L}$ (PDA - Merk)] supplemented with six concentrations (0.01, 0.1, 1.0, 10.0, 20.0 and $40.0 \mathrm{mg} / \mathrm{L}$ of active ingredient) of the following fungicides: Carbendazim (Derosal $500 \mathrm{SC}$ ), epoxiconazole (Opus 125 SC), flutriafol (Impact 200 SC), and tebuconazole (Folicur 200 EC), as well as a control (no fungicide).

Five monosporic strains, isolated from soybean leaves showing TLS symptoms, were collected in three different stages and assigned: 01/MG (Minas Gerais, line), 05/MS (Mato Grosso do Sul, Monsoy 8001), 19/MS (Mato Grosso do Sul, line), 21/MS (Mato Grosso do Sul, Monsou 8336), 35/RO (Rondonia, line)

Fungicide stock suspensions were prepared by dissolving the commercial fungicide formulation in sterile deionized water (SDW) until use. They were then further diluted to obtain the desired concentration and poured into plastic Petri dishes (90 $\mathrm{mm}$ diameter).
The day after culture medium preparation, $6 \mathrm{~mm}$-diameter mycelial plugs of each isolate, taken from seven-day-old colonies, were placed on the center of each dish. The plates were sealed with PVC plastic film and incubated in a growth chamber at $25^{\circ} \pm 2^{\circ} \mathrm{C}$ and $12 \mathrm{~h}$ photoperiod provided by three fluorescent $40 \mathrm{~W}$ lamps placed at $50 \mathrm{~cm}$ above the plates. When the colony in the control treatment reached the edge of plates, the diameter of all colonies was measured with a digital calliper.

A completely randomized experimental design using four replicates was adopted. A Petri dish was used as an experimental unit. Data on fungal colony diameter were transformed into growth percentage. Fungus plugs showing $6 \mathrm{~mm}$ diameter were disregarded as they represented only $7.34 \%$ of total growth.

Data underwent regression analysis as log transformation, using the Constat statistical program. The $\mathrm{IC}_{50}$ for fungal mycelial growth, considering fungicides and isolates of $C$. casiicola, was calculated from the generated equation. The $\mathrm{IC}_{50}$ refers to the chemical concentration that inhibited $50 \%$ mycelial growth or the potential germination of viable spores (13).

Each fungicide was run in one experiment and the concentrations were the treatments. Experiments were repeated twice to ensure accuracy.

To classify the sensitivity of isolates to fungicides, the criteria proposed by Edgington et al. (7) were adopted: insensitive, $\mathrm{IC}_{50}>50$ $\mathrm{mg} / \mathrm{L}$; moderately sensitive, $\mathrm{IC}_{50}$ between 1 and $50 \mathrm{mg} / \mathrm{L}$; and highly sensitive, $\mathrm{IC}_{50}<1 \mathrm{mg} / \mathrm{L}$.

A useful tool to quantify the shift in sensitivity to a fungicide in a fungus is the sensitivity reduction factor (SRF) (11), which is calculated by dividing the $\mathrm{IC}_{50}$ of the fungal strain suspected of having reduced/ lost its sensitivity by the $\mathrm{IC}_{50}$ of the sensitive strain. SRF value of 1 means no change in sensitivity, while values $>1$ indicate the shift for sensitivity reduction $(12,13)$.

Previous baseline studies for C. cassiicola isolates were not found to calculate the SRF.

There was an interaction between the fungitoxicity of fungicides and the sensitivity of isolates (Table 3 ).

Carbendazim. The isolates $01 / \mathrm{MG}, \mathrm{IC}_{50} 0.2 \mathrm{mg} / \mathrm{L}$, and $35 / \mathrm{RO}, \mathrm{IC}_{50}$ $0.26 \mathrm{mg} / \mathrm{L}<1.0 \mathrm{mg} / \mathrm{L}$, were considered sensitive according to mycelial growth inhibition (Table 1). For both isolates, $10 \mathrm{mg} / \mathrm{L}$ concentration

Table 1. Mycelial growth inhibitory concentration $\left(\mathrm{IC}_{50}\right)$, significance $(p)$ and sensitivity reduction factor (SRF) of Corynesporea cassiicola isolates to fungicides

\begin{tabular}{|c|c|c|c|c|c|c|}
\hline \multirow{2}{*}{ Fungicide } & \multirow{2}{*}{ Atribute } & \multicolumn{5}{|c|}{ Isolate } \\
\hline & & $01 / \mathrm{MG}$ & 05/MS & 19/MS & $21 / \mathrm{MS}$ & $35 / \mathrm{RO}$ \\
\hline \multirow{3}{*}{ Carbendazim } & $\mathrm{IC}_{50}$ & 0.20 & $>40$ & $>40$ & $>40$ & 0.26 \\
\hline & $p$ & $<0.01$ & $<0.04$ & n.s & n.s & $<0.01$ \\
\hline & $\mathrm{SRF}^{\mathrm{z}}$ & 1.00 & $>200$ & $>200$ & $>200$ & 1.30 \\
\hline \multirow{3}{*}{ Cypoconazole } & $\mathrm{IC}_{50}$ & 15.26 & 16.65 & 9.21 & 12.23 & 20.32 \\
\hline & $p$ & $<0.01$ & $<0.01$ & $<0.01$ & $<0.01$ & $<0.01$ \\
\hline & SRF & 19.88 & 21.62 & 11.96 & 15.88 & 26.39 \\
\hline \multirow{3}{*}{ Epoxiconazole } & $\mathrm{IC}_{50}$ & 2.91 & 2.74 & 2.25 & 2.64 & 2.60 \\
\hline & $p$ & $<0.01$ & $<0.01$ & $<0.01$ & $<0.01$ & $<0.01$ \\
\hline & SRF & 3.78 & 3.56 & 2.92 & 3.43 & 3.38 \\
\hline \multirow{3}{*}{ Flutriafol } & $\mathrm{IC}_{50}$ & 1.89 & 0.77 & 1.26 & 1.34 & 2.18 \\
\hline & $p$ & $<0.01$ & $<0.01$ & $<0.01$ & $<0.01$ & $<0.01$ \\
\hline & SRF & 2.45 & 1.00 & 1.64 & 1.74 & 2.83 \\
\hline \multirow{3}{*}{ Tebuconazole } & $\mathrm{IC}_{50}$ & 2.21 & 2.80 & 2.22 & 1.89 & 2.07 \\
\hline & $p$ & $<0.01$ & $<0.01$ & $<0.01$ & $<0.01$ & $<0.01$ \\
\hline & SRF & 2.87 & 3.64 & 2.88 & 2.45 & 2.69 \\
\hline
\end{tabular}

${ }^{(2)}$ The lowest $\mathrm{IC}_{50}$ to calculate SRF: Carbendazim, $0.20 \mathrm{mg} / \mathrm{L}$; DMI, flutriafol $0.77 \mathrm{mg} / \mathrm{L}$. 
inhibited mycelial growth by $100 \%$. On the other hand, the isolates 05/MS (Table 1), 19/MS and 21/MS were insensitive to carbendazim, showing sensitivity loss.

The regression equations for the mycelial growth of isolates 19/ MS and 21/MS were not significant as the strains showed no response to concentration gradient.

As previous baseline studies for $C$. cassiicola isolates were not found to calculate the SRF, the $\mathrm{IC}_{50}$ of the suspected isolate was divided by the lowest $\mathrm{IC}_{50}$ value found in the present study, i.e., $\mathrm{IC}_{50}$ of suspected isolate/ $\mathrm{IC}_{50}$ of the most sensitive isolate for each of the chemical groups tested (demethylation inhibitors, DMI and methyl benzimidazole carbamate fungicides). Thus, for carbendazim, the lowest $\mathrm{IC}_{50} 0.2 \mathrm{mg} / \mathrm{L}$ (isolate 01/MG), was considered to calculate SFR.

SRF for 05/MS, 19/MS and 21/MS, from Mato Grosso do Sul, was $>200$-fold greater than that for $01 / \mathrm{MG}$ and $35 / \mathrm{RO}$ (Table 1), which means that they would require a $>200$-fold higher carbendazim concentration to obtain a $50 \%$ reduction in the mycelial growth. This confirms the hypothesis that control failure in recent seasons can be attributed to the loss of sensitivity to carbendazim by these isolates.

Cyproconazole - $\mathrm{IC}_{50}$ ranged from 9.21 (isolate 19/MS) to 12.23 $\mathrm{mg} / \mathrm{L}$ (isolate 21/MS), considered sensitive. On the other hand, $\mathrm{IC}_{50}$ was 15.26 (isolate $01 / \mathrm{MG}$ ), 16.65 (isolate $05 / \mathrm{MG}$ ) and 20.32 (isolate $35 \mathrm{RO}$ ), classified as moderately sensitive. Sensitive isolates were statistically different from moderately sensitive ones (Table 1).

The $\mathrm{IC}_{50}$ of flutriafol, $0.77 \mathrm{mg} / \mathrm{L}$ (isolate 19/MS), was adopted as reference to calculate the SRF for DMIs.

SRF for cyproconazole ranged from 11.96 (isolate 19/MS) to 26.39 (isolate $35 / \mathrm{RO}$, which means that the concentration of the active ingredient needs to be increased from 11.96 to 26.39 times to reduce mycelial growth by $50 \%$ (Table 1 ).

Epoxiconazole - $\mathrm{The}^{\mathrm{IC}}$ for epoxiconazole ranged from 2.25 (isolate 19/MS) to 2.9 (isolate 01/MG). There was no statistical difference among isolates (Table 1).

SRF for epoxiconazole ranged from 2.92 (isolate 05 ) to 3.78 (isolate 01 ). There was no statistical difference among isolates (Table 1).

Flutriafol - showed the lowest $\mathrm{IC}_{50}$ among DMIs, ranging from 0.77 (isolate $05 / \mathrm{MS}$ ) to 2.18 (isolate $35 / \mathrm{MS}$ ). There was no statistical difference among isolates (Table 1).

SRF for flutriafol ranged from 1.0 (isolate $05 / \mathrm{MS}$ ) to 2.83 (isolate 35/RO) (Table 1).

Tebuconazole - $\mathrm{The}_{\mathrm{IC}}$ for tebuconazole was 1.89 (isolate 21/ MS) and 2.80 (isolate $05 / \mathrm{MS}$ ), respectively. There was no statistical difference among isolates (Table 1).

SRF for tebuconazol ranged from 2.45 (isolate 21/MS) to 3.64 (isolate 05/MS) (Table 1).

DMI - No loss of sensitivity to DMI fungicides was found, but there was sensitivity reduction for some isolates. Isolates $01 / \mathrm{MG}$ and $35 / \mathrm{RO}$ were considered sensitive, i.e., there was no shift in sensitivity. The other strains, however, showed a slight shift in sensitivity to DMI fungicides. Cyproconazole was least toxic to all isolates (Tables 3 and 4) and isolate $05 / \mathrm{MS}$, most sensitive to flutriafol (Table 1).

Benzimidazoles and DMIs have been used in Brazil since the early 1970s and the late 1970s, respectively, to control leaf disease epidemics affecting several crops, largely due to their desirable systemic, curative and eradicative properties for a large number of crops. However, changes in the sensitivity to DMI group have been reported in Brazil for some pathogens such as Puccinia triticina Ericks. in wheat (1) and Phakopsora pachyrhizi Sydow in soybean (2).

In the present study, a fungal strain was considered sensitive when efficiently and economically controlled by a fungicide; insensitive, when not efficiently or economically controlled (i.e. mildews by triazoles); showing reduced sensitivity, when its sensitivity to a fungicide is decreased (dose-dependent), i.e., for demethylation inhibitor (DMI) fungicides (triazoles); and showing loss of sensitivity, when no longer sensitive to a fungicide (rate-independent), i.e., for carbendazim and quinone outside inhibitor (QoI) fungicides (strobilurins) (9).

All tested isolates were obtained from regions where there was some control failure. As previous baseline studies for C. cassiicola isolates were not found, SRF was calculated by dividing the $\mathrm{IC}_{50}$ of the suspected isolate by the lowest $\mathrm{IC}_{50}$ value found, i.e., suspected isolate/ less sensitive isolate, for each of the chemical groups tested (DMI and MBC fungicides).

The in vitro sensitivity of $C$. cassiicola isolates from soybean, cherry, cotton and coffee was previously reported for several fungicides $(3,1415,16,17,18)$. Carbendazim $1.0 \mathrm{mg} / \mathrm{L}$ completely inhibited the mycelial growth of all isolates.

Detection of decreased sensitivity of $C$. cassiicola to a fungicide is not unique to soybean isolates. One of the first reports of reduced sensitivity was related to the use of benzimidazoles to control the genus Corynespora in cucumber isolates (11). In tomato, Date et al. (5) found reduced toxicity for benzimidazoles and $C$. cassiicola populations resistant to $\mathrm{MBC}$ group.

The $\mathrm{IC}_{50}$ for tebuconazole has been reported for other pathosystems. The antifungal effect of tebuconazole on the mycelial growth of $C$. cassiicola isolated from acerola (Malpighia emarginata C. D.) was described by Celoto (3), and an $\mathrm{IC}_{50}<1 \mathrm{mg} / \mathrm{L}$ was determined. On the other hand, Teramoto et al. (15) found that a concentration of 100 $\mathrm{mg} / \mathrm{L}$ completely inhibited mycelial growth in cucumber, which means sensitivity reduction; the same was found for acerola (3). In our study, the lowest concentration of this fungicide capable of inhibiting mycelial growth by $50 \%$ was $1.89 \mathrm{mg} / \mathrm{L}$ (Table 3 ).

Tebuconazole, carbendazim and epoxiconazole + pyraclostrobin showed in vitro antifungal effect on mycelial growth and spore germination of C. cassiicola in acerola (3). However, under field conditions, only carbendazim showed an adequate disease control.

Teramoto (17) reported that the fungicide carbendazim had little effect in controlling target spot in cucumber crops, which may be the result of a sensitivity shift in the pathogen. Those results are similar to ours for the three isolates from Mato Grosso do Sul, while for isolates 01/MG and 35/RO mycelial growth inhibition was $100 \%$ at $10 \mathrm{mg} / \mathrm{L}$ concentration. Recently, Xavier et al (19) has also reported sensitivity reduction/loss by C. Corynespora isolates from Mato Grosso and Paraná States.

There are limited soybean cultivars resistant to the major diseases (late disease complex, target spot and soybean rust) in Brazil. General disease management is based mainly on the use of fungicides. Therefore, farmers exclusively using high-risk medium and fungicides such as DMI and MBC at an abnormally high frequency, and/or at subdosages, may shortly select less sensitive strains, as found in our study.

Our results showed the importance of establishing a sensitive monitoring program for DMI, MBC and QoI fungicides used in soybean. This action would help detect and/or confirm possible and/ or future sensitivity shift, further elucidating the epidemiological and biological aspects of $C$. cassiicola.

The soybean crop area in the 2012/13 growing season was 27 million hectares, and three sprays per hectare have exerted a tremendous selection pressure on the fungal population over this area since the 2004/05 growing season. 
Finally, the lowest $\mathrm{IC}_{50}$ values for mycelial growth generated in our study can be adopted as a reference to monitor the sensitivity of this pathogen in future surveys.

\section{ACKNOWLEDGEMENTS}

We thank the support given by CNPq.

\section{REFERENCES}

1. Arduim, F.S.; Reis, E. M.; Barcellos, A.L.; Turra, C. In vivo sensitivity reduction of Puccinia triticina races, causal agent of wheat leaf rust, to DMI and QoI fungicides. Summa Phytopathologica, Botucatu, v.38, n.4, p.306-311, 2012.

2. Blum, M. M. C. Sensitivity of Phakopsora pachyrhizi to fungicides. 2009, (Ph. D. Thesis) University of Passo Fundo, Passo Fundo.

3. Celoto, M. I. B. Fisiologia e manejo de Corynespora cassiicola (Berk. \& M. A. Curtis) C. T. Wei, causador da mancha alvo na cultura da acerola (Malpighia emarginata D. C.). 2009. (Tese Doutorado em Agronomia) - Faculdade de Engenharia, Universidade de São Paulo, Ilha Solteira.

4. Companhia Nacional de Abastecimento. 2013 Disponível em: $<$ http:// www.conab.gov.br/ >. Acesso em 25 jan. 2013.

5. Date, H., Katoaka, E.; Tanina, K.; Sasaki, S.; Inoue, K.; Nasu, H.; Kasuayama, S. Sensitivity of Corynespora cassiicola, causal agent of Corynespora target spot of tomato, to thiophanate-methyl and diethofencarb. Japan Journal of Phytopathology, .... v.7, p. 7-9, 2004.

6. Deising, H. B.; Reimann, S.; PASCHOLATI, S. F. Mechanisms and sigs nificance of fungicide resistance. Brazilian. Ournal of Microbiology, .... v. 39, n.2, p. 286-295, 2008

7. Edgington, L. V.; Knew, K. L.; Barron, G. L. Fungitoxic spectrum of benzimidazole compounds. Phytopathology, St. Paul, v. 61:, p. 42-44.1971.

8. EMBRAPA. Reunião de Pesquisa de Soja da Região Central do Brasil. Internet Resource: http://www.cnpso.embrapa.br/rpsrcb/trabalhos.php. 2010.
9. Ghini, R.; Kimati, H. Resistência de fungos a fungicidas. Jagariúna, SP: Embrapa Meio Ambiente, 2000. 78p.

10. Hasama, W. Occurrence and characteristics of resistant strains of Corynese pora melonis against benzimidazole compounds. Phytopathological society of Japan, ....v.57, n.3, p.12-318, 1991.

11. Kunz, S; Lutz, B.; Deising, H.; Mendgen, K. Assessment of sensitivity to anilopyrimidine-and strobilurin-fungicides in populations of the apple scab fungus Venturia inaequalis. Journal of Phytopathology, Berlin, v. 146, p. 231-238, 1998.

12. Reis, E. M.; Reis, A. C.; Carmona, M. A. Manual de fungicidas - Guia para o Controle Químico de Doenças de plantas. $6^{a}$ ed. Passo Fundo: Ed. Passo Fundo, 2010. 226p.

13. Russel, P. E. Sensitivity baselines in fungicide resistance research and management. Cambridge, 2004.

14. Shimomoto, Y.; Sato, T.; Hojo, H.; Morita, Y.; Takeuchi, S.; Mizumoto, H.; Kiba, A.; Hikichi, Y. Pathogenic and genetic variation among isolates of Corynespora cassiicola in Japan. Plant Pathology, ...., v. 60, p. 253-260, 2011

15. Silva, W. P. K.; Multani, D. S.; Deverall, B. J.; Lyon, BR. RFLP and RAPD analyses in the identification and differentiation of isolates of the leaf spot fungus Corynespora cassiicola, Australasina. Journal of Botany,.... v. 43, p. 609-618, 1995.

16. Teramoto, A.; Martins, M. C.; Fischer, I. H.; Angeli, S. S.; Schimidt, D. F.; Veiga, J. Controle químico in vitro de Corynespora cassiicola, agente causal da mancha alvo em pepino. Fitopatologia Brasileira, Brasília, DF, v. 37, p. 85-86, 2004.

17. Teramoto, A.; Salvaia, A.; Martins, M. C. Sensibilidade in vitro de Corynespora cassiicola obtidos de diversas culturas a fungicidas. Congresso Paulista de Fitopatologia. Botucatu, SP, Brasil, 39. 2005.

18. Teramoto, A. Caracterização morfológica, fisiológica, isoenzimática e controle de isolados de Corynespora cassiicola (Berky \& Curt) Wei, agente causal da mancha alvo. 2008. (Tese Doutorado), Universidade de Goiás, Goiânia. 2008.

19. Xavier, Sheila A.; Canteri, M. G.; Barros, Daiane C. M. and Godoy, Claudia V.. Sensitivity of Corynespora cassiicola from soybean to carbendazim and prothioconazole. Trop. plant pathol. [online]. ahead of print, Epub Aug 02, 2013. 